IRSH 60 (2015), Special Issue, pp. 95 -I I 9 doi:I0.10I 7/So0208 590 I 5000346 (C) 2015 Internationaal Instituut voor Sociale Geschiedenis

\title{
Labor Control and Mobility in Japanese-Controlled Fushun Coalmine (China), I 907-1932*
}

\author{
L I M IN TEH \\ Institute for Area Studies, Leiden University \\ Arsenaalstraat I, 23 I I CT Leiden, The Netherlands \\ E-mail: 1.m.teh@hum.leidenuniv.nl
}

\begin{abstract}
The prevalence and persistence of labor contractors in China's mining industry during the first half of the twentieth century is frequently attributed to foreign management's avoidance of directly managing Chinese laborers. However, in Japanese-controlled Fushun Coalmine, Japanese management's reliance on labor contractors over four decades (1907-1945) represented an expansion in management's reach in labor management. In this article, I examine the period of Japanese control (1907-1932), during which Japanese mine managers resorted to bureaucratic means to control labor contractors. Using labor process theorists, particularly Richard Edwards, to read company archival documents, I argue that salient features of the Chinese labor market, namely Chinese migrant labor's mobility and international competition for Chinese labor, compelled Japanese managers to extend control over labor contractors.
\end{abstract}

The greedy, cruel, and parasitic labor contractor looms large in Fushun mineworkers' cultural memory. A compilation of Fushun area folk songs, collected between 1984 and I986, contains several songs about labor contractors. One such song is Daguiben [“Mean Big Boss”]:

Mean big boss, mean big boss

Daguiben, daguiben

Cheats us with his abacus! What a cheat! Suanpanzi neng chi ren! Neng chi ren!

Coal is produced as fast as flowing water, Bie kan meitan ru liushui,

Yet we miners have no money to bury Kuanggong wuqian zang bieqin. ${ }^{\mathrm{I}}$ our parents.

Dagui, or big boss, was what miners called labor contractors. According to the editor's annotations, this song originated among Chinese mineworkers in the

* I would like to thank Ad Knotter and David Mayer for their hard work in molding my rough draft into a presentable article. I would also like to thank all participants in the "Migration and Ethnicity in Coalfield History" workshop, held at NIAS, The Netherlands, 5-6 November 2014, which Ad Knotter organized.

I. Sun Hongjun (ed.), Fushun minge [Fushun Folk Songs] (Fushun, 1986), p. 59. 
Longfeng underground pit of Fushun Coalmine in north-east China (Manchuria) when it was under Japanese control, eventually gaining popularity among all Chinese mineworkers in Fushun because its lamentation of the contractors' "brutal exploitation" [canku boxue] resonated with the miners. ${ }^{2}$ The miners' recognized their tragic lives in the song: they labored to produce vast quantities of coal, yet the contractor paid them so little that they could not even afford to bury their parents.

Other songs used the predator motif to emphasize the contractors' greediness, cruelty, and parasitism. One song, titled Kuanggong buru zuo ma niu ["Miners are like horses or cows"], compared miners to horses and cows, and contractors to tigers and wolves. ${ }^{3}$ Another song, Gongren nan taitou ["Workers cannot hold their heads up high"], decried guizi ["Japanese devils"] for eating workers' flesh and Chinese labor contractors for gnawing workers' bones, making it impossible for workers to stand up for themselves. ${ }^{4}$ Implied in this song is the dependence of Chinese contractors on their Japanese masters. Too weak to be masters in their own right, these contractors derived their authority from becoming lackeys for the Japanese colonizers.

Predictably, Japanese mine management presented a drastically different picture of labor contractors. To Japanese mine management, labor contractors were integral - though low-level - functionaries in a modern bureaucracy. A Chinese-language textbook for Japanese personnel in Fushun Coalmine offers an apt instance of such representation. In a section with the heading, "What a contractor should know", a Chinese contractor details his duties:

The most important duty is the matter of recruitment. You must find on your own the workers you need. As a batou [contractor], you must properly supervise your workers in the underground pit by following directives from the Japanese and directing your workers accordingly. As a batou, you should readily train the mineworkers under your supervision. As a batou, on a regular basis, you must work closely with the Labor Affairs Department to diligently supervise your workers' morals and to guide their thoughts. ${ }^{5}$

In the latter half of this dialogue, the Chinese contractor excuses himself from the conversation, announcing that he has to attend a batou meeting. ${ }^{6}$ Like a bureaucrat, the labor contractor performs his duties, follows directives, coordinates with other bureaucrats, and attends meetings. At the

2. Ibid.

3. Ibid., p. 67.

4. Ibid., p. 64.

5. Minami manshū tetsudō kabushiki būjun tankō shōmu ka [South Manchuria Railway General Affairs Department], Nichi-Man taiyaku kōzan yōgoshü [Japanese-Chinese Parallel Text, Mining Vocabulary] (Būjun, I935), p. I58.

6. Ibid., p. І6г. 
same time, the control function refers not only to the behavior of the workers but also to their thoughts and minds.

The discrepancy between these two representations of labor contractors reflects the power dynamics of the economic relations binding management and workers. Mine management, driven by the profit imperative, saw labor contractors as an extension of a bureaucracy committed to extracting maximum labor power from mineworkers, who surrendered all control over themselves in exchange for wages. As such, the editor of the volume on Fushun folk songs is right in noting that mineworkers resented labor contractors as much as they resented Japanese mine management. But this interpretation misses fundamental shifts in the forms of labor control and the nature of mining work that occurred in Fushun Coalmine. That labor contractors became bureaucrats is a notable development. The regimentation and scrutiny of mining work is another significant change. To mineworkers, these changes meant little except for making their work even more unpleasant.

In this article, I investigate how the labor contractor became a bureaucrat in Fushun Coalmine. The bureaucratization of the labor contractor position was part and parcel of the bureaucratization of labor control in the mine. Drawing from labor process theory, I argue that bureaucratization stemmed from conflicts and contestations among actors inside and outside the workplace. As developments in Fushun Coalmine illustrate, mine management's desire to exert control over a highly mobile workforce, who expressed their resistance by, for example, singing subversive folk songs and by leaving at will, provided the impetus for bureaucratization, which was further propelled by international politics.

The article begins with sections on the historiography of labor contractors in modern China and on theories of labor control and bureaucratization. This is followed by a discussion on the challenges that geology and migration presented to Japanese management. Subsequent sections explain how management used bureaucratization to control migration flows to Fushun and how international politics further catalyzed the bureaucratization process. Finally, I examine mineworkers' mobility as a counterpart to bureaucratization and labor control.

\section{CONTRACTORS AND THE CHINESE INDUSTRIAL WORKER}

During the early phases of economic modernization in late nineteenth- and early twentieth-century China, the industrial workforce came from traditional craft industries, the urban population, and the countryside. To recruit these workers, factory management relied on three methods of labor recruitment: direct hiring, apprenticeship, and labor contractors. Of the three 
methods, the labor contractor system was the most prevalent. Labor contractors, known as baogong or batou, had precedents in Chinese economic history. Because the contract system had been an institution in the Chinese traditional economy, Chinese modernizers in the I920s and I930s viewed it as a vestige of China's past that impeded economic development. ${ }^{7}$ Boris Torgasheff, a mining consultant based in China, claimed that contractors prevented the introduction of technological change in mines. $\mathrm{He}$ argued that a modern mining labor force could be created only when mine management directly recruited and supervised mine labor. ${ }^{8}$ Not surprisingly, when organizing Anyuan mineworkers in the I 920 s the Chinese Communist Party leaders, especially Liu Shaoqi, railed against the contractors for their collusion with mine owners and secret societies. ${ }^{9}$

For labor historians, the prevalence of labor contractors in the modernizing Chinese economy reflected conditions specific to the Chinese context and were not indicative of a structural deficiency in Chinese modernization. As Chesneaux explains in his landmark work on the Chinese labor movement, the labor contract system was particularly common in foreign-owned factories, since foreign management had little knowledge of and contacts in local society, and so had to rely on third-party intermediaries to procure its labor supply. ${ }^{\mathrm{IO}}$

In his study of the contract labor system in the pre-1937 Chinese mining industry, Tim Wright, however, contends that foreign ownership only partially accounted for the widespread use of this labor recruitment method. Wright discovered that Chinese-owned mines were just as likely to use labor contractors as foreign-owned mines. Rather, the prominence of a contract system was generally due to problems in "the early stages of a country's industrialization", and not to a country's history, culture, or society. Based on his comparison of the labor contract system in the Chinese mining industry with other instances worldwide, Wright concludes that the emergence of a regional or national labor market would provide industries with a steady supply of skilled labor, thereby rendering the contract system irrelevant. In other words, the contract system functioned as a stop-gap measure at a time when demand for labor far exceeded supply, and fragmentations in the labor market prevented direct hiring. ${ }^{\mathrm{II}}$

7. Gu Zhanran, “Zhongguo baogongzhi [China's Contract Labor System]”, Duli pinglun, I (1932), pp. IO-I6.

8. Boris Torgasheff, "Mining Labor in China, Pt 2", Chinese Economic Journal, 6 (1930), pp. 510-54I.

9. The Anyuan coalmine is located in the present-day city of Pingxiang, Jiangxi province. See Elizabeth Perry, Anyuan: Mining China's Revolutionary Tradition (Berkeley, CA, 201 2).

I0. Jean Chesneaux, The Chinese Labor Movement, 1919-1927 (Stanford, CA, I968), p. 60.

I I. Tim Wright, “A Method of Evading Management: Contract Labor in Chinese Coal Mines before 1937”, Comparative Studies in Society and History, 23 (198I), pp. 656-678. 
By putting the Chinese instance in a global context, Wright's account highlights important similarities between the pre-I937 Chinese economy and other industrializing economies. But his conclusion leans too heavily on classic economic theory which treats labor markets as commodity markets, and supposes that the market mechanism would eventually resolve problems of inefficiency such as the labor contract system. This conception of the labor market limits our understanding of it. $^{\mathrm{I2}}$ The buying and selling of labor power entails more than a simple transaction of money for commodity; it takes place at the intersection of complex social processes. Because of the social nature of labor, changes in labor markets and labor relations come about as a result of conflict and contestation between workers, employers, households, organizations, and states. ${ }^{13}$ Conflict and contestations between these actors contributed as much as local conditions to shaping the peculiarities of labor markets, labor recruitment methods, and labor control.

\section{LABOR CONTROL AND BUREAUCRATIZATION}

During the years 1907-1932, Japanese mine management, in a long drawn-out process, transformed labor contractors from independent third-party contractors (who would oversee labor recruitment, supervision, and welfare) to salaried pit foremen with clearly defined responsibilities in labor recruitment and supervision. This transformation belongs to a broader change in the mine's labor control that bears much resemblance to what sociologist Richard Edwards called "bureaucratic control". Changes in the labor contract system accompanied other measures to standardize wages, to regulate labor recruitment and the allocation of jobs, and to install a clear hierarchy of authority that subordinated Chinese contractors to Japanese management.

Bureaucratization is often presented as antithetical to efficiency, which is the guiding principle of scientific management and a fundamental requirement for making profits. Yet, as corporations grow in scale, they become more bureaucratized. Management resorts to bureaucratic means, like rules and procedures to ensure uniformity in decision-making. To account for this change in labor control during the twentieth century, Richard Edwards identified three types of labor control: simple, technical, and bureaucratic.

Under simple control, the owner or manager exercises direct control over labor, oftentimes in person. Because bosses personally intervene "to exhort

I 2. Cf. David Harvey, The Urban Experience (Baltimore, MD, 1989), p. 19; Jamie Peck, Work-place: The Social Regulation of Labor Markets (New York, I996).

I 3. Mark Granovetter and Charles Tilly, "Inequality and Labor Processes", in Neil J. Smelser (ed.), Handbook of Sociology (Newbury Park, CA, I988), pp. I75-221, I79-180. 
workers, bully and threaten them, reward good performance, hire and fire on the spot, [and] favor loyal workers", they "generally act as despots, benevolent or otherwise", with "little structure to the way power was exercised and workers were often treated arbitrarily". ${ }^{4}$ In contrast, technical and bureaucratic controls utilize impersonal forms of technology and bureaucracy to structure the exercise of power. Technical control involves the embedding of controls in the "physical structure of the labor process", and therefore "the assembly line [becomes] the classic image [of technical control]". Is Bureaucratic control is defined by the "institutionalization of hierarchal power", which means that "'rule of law'the firm's law - replaces 'rule by supervisor command' in the direction of work, the procedures for evaluating workers' performance, and the exercise of the firm's sanctions and rewards; supervisors and workers alike become subject to the dictates of "company policy"' ${ }^{16}$ These three forms of labor control correspond to the evolution in capitalist production from small, unmechanized factories to large, mechanized factories owned by modern corporations.

Edwards's typology of labor controls under capitalist production is not the only account of how corporate management in the twentieth century became large bureaucracies, ${ }^{17}$ and the concept of bureaucratic control has been criticized, ${ }^{18}$ but I hesitate to reject wholesale Edwards's concept of bureaucratic control. The point about rules and procedures as a means of labor control is still valid, especially when these rules and procedures become the basis of management's claim to control. Management introduces rules and procedures to the labor process - hiring, allocation of jobs, organization of work, and oversight of work - in order to legitimize its own role and to delegitimize the roles of the individual foreman or contractor. The outcome, of course, is that management, if it takes its own premises seriously, has to submit to these rules and procedures, alongside everyone else. In other words, bureaucratization is not an abstract force acting on the labor process, but an integral component of conflict and contestation among contending actors.

In Fushun Coalmine the introduction of rules and procedures reflected the endeavor of Japanese managers to insert themselves into the labor process and to diminish the influence of individual contractors. Bureaucratization spanned two decades and entailed two processes.

14. Richard Edwards, Contested Terrain: The Transformation of the Workplace in the Twentieth Century (New York, 1979), p. I9.

is. Ibid., p. 20.

I6. Ibid., p. 2 I.

17. See, for instance, Michael Burawoy, Manufacturing Consent: Changes in the Labor Process under Monopoly Capitalism (Chicago, IL, 1979).

I8. See, for instance, Granovetter and Tilly, "Inequality and Labor Processes", pp. 179-180. 


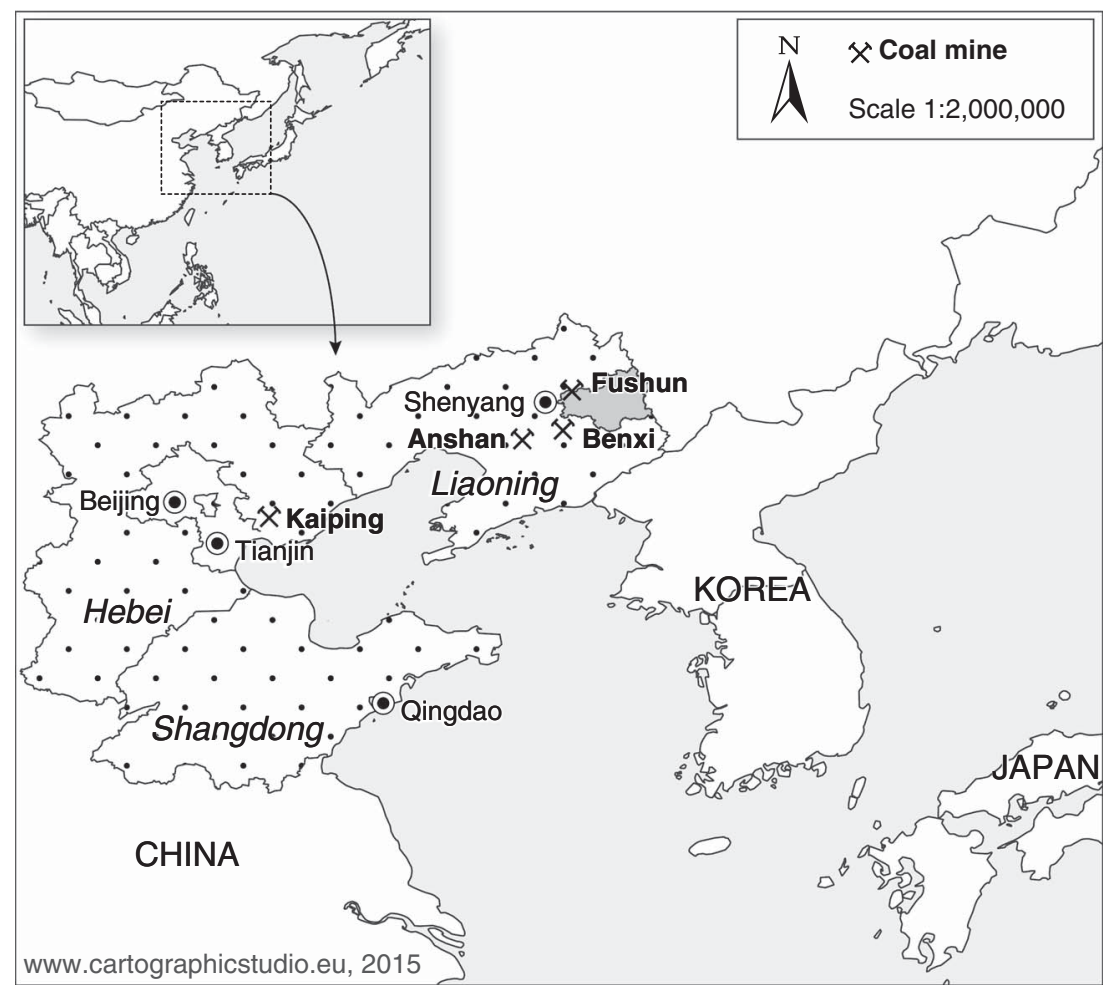

Figure r. The location of Fushun in north China/Manchuria.

One was management's piecemeal takeover of most contractors' duties in relation to labor recruitment, supervision, and welfare, and the other was the incorporation of contractors into management.

\section{FUSHUN COALMINE}

The city of Fushun (Figure I) is located in the Hun River Valley, between Shenyang (the provincial capital) and the Changbai Mountains, a mountain range that separates China and Korea. The city sits on top of a coalfield formed about 50 to 60 million years ago and discovered at the end of the nineteenth century. A handful of Chinese businesses first mined outcroppings in the coalfield in 1900 and quickly encountered financial difficulties. Loans from Russian investors sustained these companies for a few years until Japanese victory in the Russo-Japanese War (1904-1905) transferred ownership into Japanese hands. The South Manchuria Railway Company (SMR), a joint-stock company that the Japanese state formed and controlled, took over these companies. For the next forty years, the SMR managed 
Fushun Coalmine through the tumult of the Japanese invasion in I93 I and the establishment of the nominally independent Manchukuo nation-state in 1932 until the Japanese empire fell in I945.

During the first two decades of control, Japanese engineers and mine managers faced the unique challenge of twin abundance: energy resources and labor. The coalfield in Fushun possessed an exceptionally thick coal seam relatively close to the earth's surface. The main coal seam spanned about I6 kilometers in length and 3 kilometers in width, and measured in depth 24 meters at its thinnest and 146 meters at its thickest. Japanese geologists initially estimated the deposit at I.2 million tons. ${ }^{19}$ This estimate was revised in the 1920 s to 750 million tons and subsequently in the 1980 s to 950 million. ${ }^{20}$ Coal analysis indicated that Fushun coal contained minimal sulfur and moisture, possessed a high heating point, and thereby belonged to the class of bituminous coal. These inherent qualities of Fushun coal made it suitable for making coking coal, heating furnaces, powering steam engines, and generating electricity. When Japanese management took over mining operations in 1907, the mine was producing about 234,000 tons of coal. Thirty years later, in I937, the mine reached its peak output of 10.34 million tons, accounting for one-quarter of the entire coal output in Manchuria and China. ${ }^{21}$

The technical solutions to mining Fushun's thick coal seam inevitably shaped the organization of mining work. The corresponding mining techniques long-wall mining, inclined shaft, sand filling-in, and open-cut - demanded a highly structured organization of work and a highly regimented approach. A sharp division of labor emerged especially in the underground pits, separating hewers from haulers, timberers, sweepers, and odd-job generalists. ${ }^{22}$ At the same time, precise times for eight-hour work shifts, safety equipment and

19. The South Manchuria Railway, Manchuria: Land of Opportunities (New York, 1922), pp. 34-35.

20. The r 930 s estimate was provided by Japanese geologists and engineers to William M. Quackenbush and Quentin E. Singewald, members of the US Army's Mining and Geological Division. See William M. Quackenbush, "Fushun Coalfield, Manchuria, Report no. 68, I7 February 1947", Tokyo General Headquarters, Supreme Commander for the Allied Powers, Natural Resources Sect. [1947]. South Manchuria Railway documents on Fushun Coalmine used in this article have been consulted at the United States Library of Congress, Jilin Province Academy of Social Sciences, and the Liaoning Provincial Archives. The estimate in the r 980 s is reported in Edward A. Johnson, "Geology of the Fushun Coalfield, Liaoning Province, People's Republic of China”, International Journal of Coal Geology, I4 (1990), pp. 2 I7-236.

21. Minami manshū tetsudō kabushiki būjun tankō [South Manchuria Railway Fushun Coalmine], Bujun tankō tōkei nenpō [Fushun Coalmine Annual Statistics] (Fushun, 1942); Tim Wright, Coal Mining in China's Economy and Society, I895-I937 (Cambridge, 1984), Appendix B.

22. This high degree of specialization intensified in the 1930 s with the introduction of electricand steam-powered hand tools in underground pits. I discuss this in greater depth in my dissertation: Limin Teh, "Mining for Differences: Race, Chinese Labor, and Japanese Colonialism in Fushun Coalmine, 1907-1945" (Ph.D., University of Chicago, 2014). 
checks, and strict work rules were introduced. As such, mineworkers in Fushun Coalmine were subjected to a discipline that was more commonly found on a factory assembly line than in traditional mines. To the newly recruited mineworkers who had never encountered such discipline, it might not be an exaggeration to say that they found themselves no more than cogs in a wheel. More than a few recruited mineworkers rejected this discipline and left. I discuss this common practice of leaving in greater detail below.

\section{LABOR SUPPLY AND MIGRATION}

The second abundance that challenged mine managers was the great quantity of Chinese labor due to longstanding migration from north China to Manchuria. ${ }^{23}$ Manchuria was a peripheral frontier whose population base was too low for emerging industries like Fushun Coalmine, while the region to its south, north China, was far more densely populated. From I 890 to I94 I about 25 million people travelled between Manchuria and north China, with 8 million settling permanently in Manchuria and I7 million returning to north China. According to historians Diana Lary and Thomas Gottschang, the migration to Manchuria was one of the largest population movements in twentieth-century world history. ${ }^{24}$

To SMR management, this migration proved as much a boon as a bane. Takeo Itō, the head of the SMR research bureau, articulated the positive perspective of this migration. In his autobiography, Itō commented that "Chinese laborers, not only longshoremen, but also as wagon drivers, factory workers, and coalminers, came pouring into Manchuria. And peasants and laborers on the Chinese mainland were an inexhaustible supply." 25 At the same time, this "inexhaustible supply" of labor came with problems. Another SMR researcher, Isamu Abe, complained that "whereas Manchuria does not lack unskilled hands such as coolies there are very few who are more or less experienced in factory work" ${ }^{26}$ Abe's complaint about the perceived flaws of Chinese migrant labor is elaborated in another company report comparing Japanese and Chinese workers. In this report, the SMR observed that Japanese workers "show a tendency to remain stationary", and their "efficiency may be 30 to 40 per cent higher than the

23. The macro-region of north China consists of Hebei, Shandong, Henan, and Shanxi provinces. Hebei and Shandong were the main provinces that sent migrants to Manchuria in the first half of the twentieth century.

24. Thomas R. Gottschang and Diana Lary, Swallows and Settlers: The Great Migration from North China to Manchuria (Ann Arbor, MI, 2000), p. 2.

25. Ito Takeo, Life along the South Manchurian Railway: The Memoirs of Ito Takeo (Armonk, NY, I988), p. 48.

26. Isamu Abe, The Economic Development of Manchuria: Japan's Contributions (Dairen, I93 I), p. 26. 
Chinese" ${ }^{27}$ Conversely, Chinese workers were regarded as highly mobile and inefficient.

Japanese management frequently relied on the racial ideology of Japanese imperialism to validate their claims about the inferiority of Chinese labor. As historians of Japanese imperialism and Sino-Japanese relations have argued elsewhere, the racial ideology that underpinned Japanese imperial expansion into China crystallized with the Japanese victory in the First Sino-Japanese War (I895-I896). ${ }^{28}$ This victory confirmed, in the eyes of Japanese elites, Japan's ascendancy and imperial China's rapid descent. Subsequently, science and history were mobilized to construct a racial ideology that justified Japanese superiority and Chinese inferiority. Whereas the racial ideology of Western imperialism ascribed negative meanings to somatic attributes of its colonized subjects, the racial ideology of Japanese imperialism ascribed negative meanings to the cultural attributes of its Chinese subjects. Hence, the source of Chinese inferiority was Chinese culture. Accordingly, Japanese management in Fushun explained that "because their outlook on life is unstable, the Chinese workers tended to be dull-witted, ill-tempered and unsystematic". ${ }^{29}$ Culture is substituted here with the code phrase "outlook on life".

These traits of Chinese migrant labor, however, lay not with "culture" or "race", but in migration itself. Migration from north China to Manchuria had a history that predated Japanese arrival in I905 and was based on institutions that were independent of Japanese control. This migration became such a widespread social phenomenon that it acquired a proper name. To migrate to Manchuria is to chuang guandong, or to travel east past the gates, though the verb chuang connotes intrusion or forceful entry. When the Japanese arrived in 1905 , they stimulated this migration by improving the existing transportation infrastructure and by enlarging the demand for labor. Although Chinese migrants rode in Japanese-owned steamships and railroads to work in Japanese-controlled factories and mines, the forces that drove these migrants from their homes in north China and the dynamics that regulated the migrants' movement were far beyond Japanese control.

27. The South Manchuria Railway, Third Report on Progress in Manchuria, 1907-1932 (Dairen, I932), p. I I7. The SMR distributed these English-language annual reports to libraries worldwide. This was likely part of the Japanese government's broader campaign to demonstrate to Western nations Japan's role in modernizing China.

28. Mark Peattie, "Introduction", and "Japanese Attitudes Towards Colonialism, I 895-1945", in Ramon H. Myers and Mark Peattie (eds), The Japanese Colonial Empire, I895-1945 (Princeton, NJ, 1984), pp. 3-60 and 80-I 27; Stefan Tanaka, Japan's Orient: Rendering Pasts into History (Berkeley, CA, 1995).

29. Minami Manshū Tetsudō Kabushiki Kaisha [South Manchuria Railway] [Mantetsu], Minami Manshü Tetsudō Kabushiki Kaisha Dainiji Jünenshi [Second Ten-Year History of the South Manchuria Railway] (Dairen, I928; repr. Tokyo, 1974), p. 570. 
The migrants from north China to Manchuria were of two types: sojourning workers and settlers. The former made up the majority, especially in the igoos and I9ros. Almost all of them came from farming households. They resorted to supplementing their household incomes with seasonal work in Manchuria when crop yields, falling cotton prices, and heavy taxes deteriorated living conditions. For those whose farming plots were simply too small to yield enough income, they sought seasonal work in hopes of purchasing more land. Regardless of the reason for their leaving, these sojourning workers eventually returned to tend their land. ${ }^{30}$

The number of permanent settlers and temporary migrants increased dramatically in the twentieth century when the political and economic conditions in north China plunged to previously unknown depths. The Qing state's collapse in I9 I I precipitated almost two decades of continuous warfare among rival regional warlords. In the period I 91 2-1930, there were only two years, I9I 4 and I9I 5 , during which military conflict did not occur in north China. ${ }^{3 \mathrm{I}}$ These warlords also intruded into the lives of ordinary Chinese in other ways, from heavy taxation to forced conscription to plundering villagers' provisions for their armies. Compounding the problems of warlordism was a series of natural disasters visited upon the region. These natural disasters - flooding, drought, hail, and locust infestation - depressed crop yields and displaced millions. ${ }^{32}$

While worsening political and economic conditions in north China forced millions to leave their farmlands, the growing Manchurian economy lured those displaced to Manchuria in search of employment and political stability. Between the Russo-Japanese War in I90s and the Japanese invasion in I93 I, Manchuria's economy flourished. Japanese enterprises like the SMR embarked on large-scale urbanization and industrial projects that created plenty of jobs for migrant workers from north China. Jobs in these Japanese-owned industrial enterprises paid higher wages than those in Chinese-owned enterprises, and required fewer daily working hours. In I929, a Chinese worker in a Japanese-owned enterprise earned an average daily wage of ¥o.6I and worked an average of 9.58 hours daily, whereas a Chinese worker in a Chinese-owned enterprise earned an average daily wage of $¥ 0.36$ and worked an average of I I.28 hours. ${ }^{33}$ Chinese migrant workers - both temporary sojourners and permanent settlers - flocked to these higher-paying jobs in Manchuria's growing industries.

30. Gottschang and Lary, Swallows and Settlers, p. 4I.

31. Fan Lijun, Jindai guannei yimin yu zhongguo dongbei shehui bianqian [Modern Migration from within the Great Wall and the Development of North-East Chinese Society] (Beijing, 2007),

p. I 44 .

32. Gottschang and Lary, Swallows and Settlers, pp. 56-59.

33. South Manchuria Railway, Third Report on Progress in Manchuria, pp. I 57-I 59. 
Facilitating this population movement was an infrastructure of transportation and communication, consisting of buffalo carts, railways, steamships, and inns. In addition to its relatively comprehensive coverage of the routes traveled, this transportation infrastructure was also surprisingly affordable. Three large transportation companies - Shandong Railroad, Dalian Steam Shipping Company, and SMR - dominated the market. In I 9 I 8, these three companies offered Shandong migrant workers heading to Fushun an attractive package of discounted railway and steamship tickets at the price of $¥ \mathrm{I}$.50. This was the equivalent of three days’ work for a hewer in Fushun Coalmine and seven days' work for a hewer in Zichuan Coalmine in Shandong, about 780 kilometers from Fushun. ${ }^{34}$ So low were transport costs that travel times were probably more prohibitive. It took up to ten days to travel the shortest distance from Zhifu in Shandong province to Fushun, and more than ten days for those migrants living in remote villages far from transport routes.

\section{LABOR CONTRACTORS}

Recruitment for this migration relied on existing networks in rural society. Similar to other instances in the global history of migration, social networks based on native place and kinship were activated to sustain the migration from north China to Manchuria. Existing native place and kinship ties enabled returning migrants to recruit others from their villages and families by sharing stories of success and information about the destination. ${ }^{35}$ In rural north China, where native place and kinship often overlapped, villagers were more likely to trust returnees than random strangers, even if the returnee did not hold any position of authority in village society. This made returnees ideal recruiting agents. The enterprising ones parlayed their position, knowledge of local society, and contacts in Manchuria's flourishing industries into careers as labor contractors.

For Japanese industrial enterprises in Manchuria this recruitment dynamic proved beneficial in securing a steady labor supply. Because contractors need not be authority figures in their village, any enterprising worker could become one, and consequently there was no shortage of contractors. Moreover, Japanese management was able to handpick those contractors who seemed most trustworthy in view of the inevitable (and potentially detrimental) allegiances these had to family and village societies. The career paths of two contractors in Fushun Coalmine, Zheng Fuchen and Xu Diankui, illustrate the convenient overlapping of migration and labor recruitment. Zheng was originally from Kaiping, where the first

34. Fujihirada Bunkichi, Manshū ni okeru kōyama rōdō sha [Mineworkers in Manchuria] (Dairen, I9I8), pp. 3I-33.

35. Ibid., p. 49. 
modern coalmine in China was started in 1877 , while Xu moved from his birthplace in Shandong to Xinqiu (today a district in Fuxin, Liaoning province), where his father worked as manager of a coalmine. ${ }^{36}$ Having come from mining communities in Kaiping and Xinqiu, to Japanese management they proved attractive candidates as labor contractors. They knew enough about mining techniques to train and supervise others at work. More importantly, their knowledge of these communities made labor recruitment easy. By the late igios, both men had become powerful contractors in Fushun Coalmine, each overseeing 500 to 700 mineworkers. Most of their workers came from their own native places. ${ }^{37}$

Contractors shared native place and even kinship ties with the migrants, but these ties were not binding to the point of coercion. They possessed limited control over the recruited migrants, especially after the migrants arrived in Manchuria. As noted in Gottschang and Lary's work, migrants moved easily and freely upon their arrival in Manchuria, leaving jobs they found unsuitable for more lucrative ones, including banditry. ${ }^{38}$ In the first decades of the twentieth century, Japanese officials reported at least 300,000 migrants entering and at least 200,000 leaving Manchuria annually. ${ }^{39}$ As these figures suggest, the migrating population was highly mobile. The contractor's weak hold over the recruits was largely because of the low hurdles and risks involved in making this journey. As mentioned earlier, the transportation and communication infrastructure was established and affordable. Furthermore, there was hardly any state oversight on population movement to and inside of Manchuria. Until 1932, the absence of a centralized state in Manchuria meant that there were no controls over population movement within, and in and out of Manchuria. The paucity of statistical figures on migration, especially by the Chinese state, exemplifies the state of affairs. It was only after 1932 that the Manchukuo regime imposed control over the mobility of labor, but with limited success.

\section{BUCREAUCRATIZATION OF LABOR CONTROL IN FUSHUN COALMINE}

Despite the shortcoming of the labor contractors in terms of actual labor control, dependence on them was widespread in Manchuria's industries, especially in Japanese-owned enterprises. Almost all Japanese enterprises relied on the labor contract system for labor recruitment. The exception was

36. Ibid., pp. 49-50.

37. Yu Heyin, Kuang ye baogao: Fushun meitan [Report on Mining: Fushun Coalmine] (Beijing, I927), p. I46.

38. Gottschang and Lary, Swallows and Settlers, p. 58.

39. See Appendix A in Gottschang and Lary, Swallows and Settlers, for detailed figures of entries and departures from Manchuria I89I-I942. 
Fushun Coalmine. Unlike its peers, Japanese management in Fushun Coalmine sought to rectify the shortcomings of labor contracting by extending bureaucratic control over the contractors. Because labor contractors interfaced between the worlds of Japanese-controlled Fushun Coalmine and Chinese migration to Manchuria, mine management assumed that control over contractors would grant it control over the migration.

From the time the SMR took over Fushun Coalmine, Japanese mine management was far from content with the autonomy that labor contractors enjoyed, conveying its dissatisfaction in action and in words. In I908, mine management introduced a parallel system of direct hiring, with the company directly employing 25 per cent of all mineworkers. ${ }^{4}$ A Japanese-language company report published in 1909 included a lengthy discussion on labor contractors taking advantage of mineworkers, such as shortchanging workers' wages by manipulating the complex currency situation in Manchuria, and labor contractors' inconsequential contribution to production output. ${ }^{41}$ Mine management observed no difference in the output of direct hires and contract workers. This experiment probably emboldened Japanese mine managers to take further action to regulate labor contractors' role in providing jobs, wages, and welfare.

In I9I I Japanese mine management introduced major changes that drastically curtailed contractors' influence over mineworkers. Through a series of measures, the responsibilities of labor contractors (such as wage payment, labor recruitment, labor welfare, and labor treatment) were gradually taken over. First, mine management converted all mineworkers to the status of "direct hires", which meant that all mineworkers, including those hired under the labor contract system, received their wages directly from mine management. ${ }^{42}$ This seemingly trivial administrative move actually deprived contractors of a source of power. Contractors had frequently used this ability to determine and distribute wages to their advantage. By withholding or docking wages, they usually forced workers submit to them.

Second, mine management began assuming responsibilities traditionally associated with labor contractors, namely opening a labor recruitment center in Zhifu to recruit miners directly in Shandong. ${ }^{43}$ Third, the company embarked on constructing housing and other facilities for its miners. Two- and

40. Minami manshū tetsudō kabushiki būjun tankō [South Manchuria Railway Fushun Coalmine], Bujun tankō [Fushun Coalmine] (Dairen, 1909), p. 227.

4I. Ibid., pp. 249-250.

42. Minami Manshū Tetsudō Kabushiki Kaisha [South Manchuria Railway] [Mantetsu], Minami Manshü Tetsudō Kabushiki Kaisha Jünenshi [Ten-Year History of the South Manchuria Railway] (Dairen, I919, repr. Tokyo, 1974), p. 497; Fujihirada, Manshū ni okeru kōyama rōdō sha, pp. 24I-247; Yu, Fushun meitan, p. I45.

43. Mantetsu, Jünenshi, p. 495. 
three-story tall dormitories with modern amenities such as steam heating and running water were built. A hospital was opened to provide free medical treatment to sick or injured miners. And an entertainment complex that housed a stage for Chinese operas and supplied free musical instruments to those interested in learning to play them was erected. ${ }^{44}$ In doing so, Japanese management signaled a desire to reduce its dependence on Chinese contractors by obtaining its labor supply and providing for its laborers themselves. Fourth, management issued regulations on the treatment of newly recruited miners. In these regulations, management inveighed against the abuse of newly recruited miners and spelled out punishment for the guilty. The regulations also entitled new recruits to two months' fixed income, regardless of output. These regulations demonstrated management's efforts to cultivate loyalty among new hires and isolate abusive contractors. ${ }^{45}$

Most significant in the expansion of Japanese managerial reach were the standardization of contractors' wages and the subordination of labor contractors to Japanese management's authority. On Io September I9I I mine management issued "Regulations on Mining Workers' Contractors" [saitan kukō hatō kisoku], which separated contractors into two groups, large contractors and small contractors, with the latter assisting and subordinate to the former. ${ }^{46}$ The new regulations stated that a small contractor could supervise no more than fifty men, though there were no restrictions on the number of men that a large contractor could supervise. Monthly salaries for both groups of contractors were capped at 3.5 per cent of mineworkers' gross salaries. Under the new regulations, the chain of command began with the Japanese colliery manager at the top, followed by the large contractor and then the small contractor. Japanese colliery managers had the right to dismiss contractors for poor performance. It is impossible to ascertain how effective these regulations were in limiting the contractors' influence in the workplace, but it is possible to state that these regulations marked the end of contractors' autonomy and the start of their careers as company bureaucrats.

Between I917 and 1927, mine management expanded and intensified the bureaucratization of labor recruitment. In 1917, it issued new regulations on this issue. ${ }^{47}$ Under these regulations, management reimbursed new hires and contractors for all costs incurred in their journeys to and from Fushun. With mine management paying for travel costs and reimbursement standardized, the contractors lost control over the right to charge recruits

44. Ibid., p. 497.

45. Fujihirada, Manshū ni okeru kōyama rōdō sha, p. 243.

46. Repr. in Yu, Fushun meitan, pp. I66-I67, and Fujihirada, Manshū ni okeru kōyama rōdō sha, pp. $245-246$.

47. Fujihirada, Manshū ni okeru kōyama rōdō sha, pp. 6I-64. 
for bringing them to Fushun. In addition, these new regulations further deprived contractors of the right to decide whom to hire, and required contractors to send prospective workers to a recruitment center or branch office, where Japanese SMR staff evaluated them before approving them for employment in a coalmine. Evaluation of a miner's eligibility for employment entailed subjecting the prospective mineworker to a battery of tests to ascertain that his physical fitness and health were up to the company's standards. Those found to have lung disease, syphilis, or opium addiction were immediately rejected..$^{4}$ No longer did contractors have the final say in a miner's hiring. But to ensure that contractors were motivated to retain these recruits at the workplace, mine management implemented an incentive scheme that rewarded contractors and recruits for working thirty days in the mine.

The next step in bureaucratizing labor recruitment was to eliminate contractors as intermediaries altogether. Recruitment centers and mineapproved shops replaced contractors as proxies in recruiting and evaluating prospective miners. To this end, mine management issued regulations and procedures in 1925 to encourage workers to come to the mine of their own accord, without recruiters. As with all new hires, those who arrived on their own had their travel costs reimbursed. But before they arrived in Fushun, they had to go to recruitment centers in large cities like Qingdao or to retail shops acting as proxies for the mine. In order to become a mine-approved agent, the retail shop's owner had to be recommended by a labor contractor and personally submit a written request, and the shop had to be located at a busy intersection of a town. As mine-approved agents, these shops fingerprinted prospective workers and issued them departure certificates containing their names, ages, and fingerprints. These shops then had to inform, probably by telegraph, the mine's so-called Chinese Labor Department [C. huagong bu; J. kako bu] of the workers' arrival. ${ }^{49}$ Upon arrival, the workers had to submit their departure certificates to the Chinese Labor Department, which then verified their identities before issuing them with identity cards. For each worker who completed thirty days' work, the worker and the shop received a bonus. ${ }^{\circ}$

This system was predicated on migrant workers already knowing about the mine and its hiring practices. To ensure that knowledge about mine

48. Mantetsu, Jūnenshi, p. 567 .

49. The Chinese Labour Department dealt only with Chinese migrant workers. The General Affairs Department [C. shuwu bu; J. shōmu bu] dealt with Chinese permanent employees and Japanese employees of all ranks.

50. Regulation No. I I45, "Terms of Provisional Regulations on Rewarding Chinese Miners who Paid for their own Fare to the Coalmine", repr. in Mantie midang: mantie yu laogong [Secret Archives of the South Manchuria Railway: South Manchuria Railway and Labor] (Guilin shi, 2003), I, pp. I-8. 
recruitment practices was not restricted just to select individuals, Japanese management regularly advertised its recruitment policies. These advertising broadsheets announced the names of mine-approved proxy recruiters, that the mine reimbursed travel costs, that prospective hires needed guarantors, and that new hires had to complete thirty days of work before receiving their travel reimbursement. ${ }^{5 \mathrm{I}}$ By making the recruitment procedures public information, mine management pre-empted greedy contractors from taking advantage of prospective hires' ignorance while simultaneously rendering contractors all but irrelevant in the recruitment process.

\section{FINGERPRINTING AND IDENTITY CARDS}

Mine management's most ambitious intervention in regulating labor recruitment and mobility was the introduction of mandatory fingerprinting and identity cards in 1924. Under this new fingerprinting policy, the hiring department had to take two sets of fingerprints when it decided to hire a Chinese worker. Only the worker's left index finger was printed at this initial stage of implementation. One record (later whole sets of fingerprints) would be filed at the hiring department and another at the Chinese Labor Department, which would use the fingerprints to check the worker's background. If criminal activity was discovered in the worker's records, the worker was immediately fired. ${ }^{52}$ In the following year, mine management increased the amount of information recorded about every Chinese worker. After the worker had the prints of all his fingers taken, he had to provide the following information: department of employment; job title; job number; pay range; full name; age; place of origin; current residence; and full name of father, mother, wife, and son. This newly expanded identity card formed the basis of a rudimentary personnel file, in which management would record employment dates, reasons for dismissal, resignation, and transfers, as well as workplace fatality and injury. With information about a worker's past employment record on file, mine management could easily determine if the worker had been previously fired, transferred from another pit without permission, or stolen a dead worker's identity card. ${ }^{53}$ Mine management claimed to have disqualified from employment $\mathrm{I}, 640$ Chinese workers, out of all 34,955 workers hired in 1925 , on the basis of these workers' records. ${ }^{54}$

51. An example of such an advertisement is repr. in Yu, Fushun meitan, pp. 167-168.

52. Mantetsu, Dainiji Jünenshi, p. 572 .

53. "Fushun meikuang zhiwen guanli guicheng zhaiyi [Translated excerpt of the Fushun Coalmine Regulation on Supervision of Fingerprinting], Fu da No. 640, 1925.24", repr. in Xie Xueshi (ed.), Mantie shi zhiliao [Materials on the History of the South Manchuria Railway] (Beijing, 1987) pp. 31 5-3 I6.

54. Minami Manshū Tetsudō Kabushiki Kaisha Būjun tankō [South Manchuria Railway Fushun Coalmine], Sakugyō nenpō: Taishō jū yon nendo [Annual Report on Operations, 1925], p. 6, 
Kuribayashi Kurata, the chief of Fushun Coalmine's Chinese Labor Department, outlined the company's reasons for introducing fingerprinting and identity cards. Fingerprinting facilitated the identification and "elimination of bad elements" [furyo bunshi baijo].5 Those considered "bad elements" included those who did not pay back money borrowed from friends and batou, who were involved in strikes or labor activism, and who were fugitives fleeing the Chinese criminal justice system. Obtaining the fingerprints of each Chinese worker would facilitate the identification and elimination of these "bad elements" because, as Kuribayashi points out, they were "unchanging for life" [shyüsei fuben] and "unique for tens of thousands of people" [manjin fudō]. ${ }^{56}$

In addition to the policing of Chinese labor, Kuribayashi also argued that fingerprinting would improve Japanese management of Chinese labor. Fingerprinting allowed management to treat its very large labor force with precision. In 1927, Fushun Coalmine employed about 42,70I Chinese workers. Given the large number of Chinese workers, fingerprinting assisted Japanese management in properly meting out punishments and rewards. Also, the new fingerprinting system allowed mine management to investigate why Chinese workers left employment. The new system required the recording in each worker's personnel file of the reason for terminating employment. This would allow a better understanding of the high turnover rate. Lastly, the introduction of fingerprinting would prevent Chinese workers from taking advantage of the mess hall. Each Chinese miner paid I sen a day for his meals in the mess hall. Without proper means of identifying workers who had paid and eaten, mine management could not prevent Chinese workers from either taking a second helping or sneaking someone else into the mess hall.

It is noteworthy that Kuribayashi's arguments were presented to the Minami mansh ü kōgyōsha konwakai [South Manchurian Industrialists' Club, hereafter konwakai]. Formed in May 1926, the konwakai was a regular gathering of representatives from Japanese industrial enterprises in southern Manchuria, including the Manchuria Spinning Company and the Manchuria Candy Manufacturing Company, Anshan Steelworks, Benxihu Coal and Steel Company, and SMR branch operations like Fushun Coalmine. The purpose of these gatherings was to share and collaborate on issues related to labor management. ${ }^{57}$ The agenda of the first two meetings concerned the high turnover rate among Chinese employees at these

Library of Congress MOJı633; Būjun tankō [Fushun Coalmine], Sakugyō nenpō: Taishō jū san nendo [Annual Report on Operations, 1924], p. 6, Library of Congress MOJi632.

55. Kuribayashi Kurata, "Konwakai ni shimon jisshi nitsuite [Concerning the Implementation of Fingerprinting, Discussed at the Casual Forum]", [1927], repr. in Mantie midang, p. 50.

56. Ibid., p. 52.

57. Repr. in Mantie midang, Item 2.I, p. I I. 
enterprises. Kuribayashi's presentation was to persuade other enterprises to adopt fingerprinting and identity cards as measures to contain labor mobility.

The problem of labor mobility was so severe that all members of the konwakai readily agreed to have their Chinese workers fingerprinted. In fact, the SMR also joined in this effort by issuing a company-wide directive on 4 August 1927 that required all its Chinese employees to be fingerprinted according to the procedure established at Fushun Coalmine. ${ }^{58}$ Clearly, labor mobility affected all industrial enterprises, but the labor turnover rate was particularly high in Fushun Coalmine, which accounts for mine management's vigorous efforts to control the movement of Chinese migrant labor.

\section{INTERNATIONAL POLITICS, NEW RECRUITMENTS, AND BUREAUCRATIZATION}

The accelerated pace of bureaucratization in labor recruitment coincided with the expansion of recruitment areas. In the years I916-I918, British and French recruitment of Chinese labor in the mine's traditional recruitment areas in Shandong, which had, as described above, a long history of outmigration to Manchuria, forced Japanese management to consider new areas. Various factors led management to settle on the parts of Hebei province that had no tradition of outmigration to Manchuria. The decision attracted the attention of the Chinese state, which then demanded that Japanese management share information about the recruiters. ${ }^{59}$ Hence, the confluence of international politics resulted in mine management's trend toward bureaucratization being accelerated.

The last two years of World War I brought equal measures of fortune and misery to the mine's Japanese managers. ${ }^{60}$ Although the main theater of the war was thousands of miles away in Europe, it still affected China and the rest of Asia. The Great War caused economic recession in China and Manchuria, as fighting drastically lowered European demand for goods and commodities from Asia. When the war drew to a close, pent-up demand worldwide and reconstruction efforts in Europe stimulated economic recovery in Asia. As factories in China and Manchuria strove to meet increasing domestic and international orders, their need for coal increased accordingly. For Fushun Coalmine to meet the growing demand, it had to raise mining capacity. Since the open-cast pit in Guchengzi was far from

58. "Jitatsu dai 6I go [Directive No. 6I]". Repr. in Mantie midang, Item 9.2, p. 6I.

59. Information about recruiters and recruited workers is listed in the Fushun Mine Director's correspondence to the Republic of China Ministry of Foreign Affairs, dated 2 March I 92 I, 03 -0301 5-04-02 I, Institute of Modern History Archive, Academia Sinica, Taipei.

60. Mantetsu, Jünenshi, p. 54I. 
completion, the only viable solutions for Fushun mine management were to open up more underground workings and to hire more workers for them. Two new pits were opened in I917 and I9I8, Longfeng and Xintun respectively. Hiring grew in scale and scope in the late i9ros. The mine employed 37,057 Chinese workers in 1919, which was almost twice the total number of Chinese workers employed in $1916 .{ }^{61}$

While the end of warfare unleashed rapidly growing demand for Fushun coal, it also created conditions that threatened the supply of Chinese labor in Shandong. With the creation of the laborers-as-soldiers program in I9I 5 , a portion of the labor supply in Shandong was diverted to Europe. Under this program, the Chinese state allowed Britain and France to obtain much needed manpower by recruiting Chinese laborers and students in Shandong in exchange for both countries' support for China's campaign to regain Shandong from Japan. This program sent about I40,000 Chinese, with the majority from Shandong, to Britain and France between I916 and I921. ${ }^{62}$ Although the gross figures for laborers recruited under this program paled in comparison to the figures for north China-Manchuria migration, the proximity of French and British labor recruitment campaigns in Tianjin and Weihaiwei respectively adversely affected Japanese labor recruitment in Yantai.

This unexpected turn of events compelled Japanese management at Fushun Coalmine to broaden its recruitment areas. Despite the mine's pressing need for more laborers and the competitive pressures of French and British recruitment, Japanese management imposed restrictions on its search for new labor sources. It was not interested in expanding its recruitment campaign to Japan. Japanese labor was an expensive alternative. Not only were Japanese workers' transportation costs higher, their wages and living costs were higher too. Since its formation in I905, the SMR, including Fushun Coalmine, instituted different wage scales for Japanese and Chinese employees, with Japanese wages at least three times higher than Chinese wages. In 1926, the average daily wage for a Japanese worker was $¥ 2.48$ while that for a Chinese worker was ¥o.68. ${ }^{63}$ Indeed, in its 1908 cost-reduction efforts SMR management replaced its Japanese employees in less skilled positions with Chinese workers. ${ }^{64}$

Japanese management in Fushun Coalmine was not keen on extending its recruitment area to Korea either. As compared with Japan, Korea was closer

6I. Bujuntankō tōkei nenpō Shōwa Is nen [Fushun Coalmine Annual Statistics: 1942], Library of Congress MOJis 58.

62. Xu Guoqi, Strangers on the Western Front: Chinese Workers in the Great War (Cambridge, MA, 201 I), p. 42.

63. Mantetsu, Jünenshi, p. I40.

64. Yoshihisa Tak Matsusaka, The Making of Japanese Manchuria, 1904-1932 (Cambridge, 2000), p. I 43 . 
to Manchuria and Korean labor cost less than Japanese. When Japan annexed Korea as its formal colony in I919, Japanese companies also faced fewer barriers to Korean markets, including labor. In the late igros, all mines in Manchuria experienced labor shortages, but none of the Japanese-controlled mines in nearby Anshan and Benxihu expanded their recruitment areas in Korea. According to Fujihirada Bunkichi, an SMR staff member who in I9I 8 prepared a report on mining labor in Manchuria, Japanese managers in Anshan and Benxihu mines thought poorly of the Koreans they had hired. They found them to be "nasty drunks", who frequently fought and quarreled among themselves, "lazy", and lacking Chinese workers' "capacity for work". ${ }^{5}$ The same attitude was prevalent in Fushun.

Apart from this reluctance to use Korean laborers, Japanese management in Fushun did not wish to compete with Japanese-controlled mines in Manchuria for labor and thus it specifically prohibited its recruiters from poaching workers in Anshan and Benxi mines. This meant that Fushun mine management had to expand its recruitment territory further into rural counties in Shandong and Hebei provinces that had, up to this point, not participated in the seasonal migration to Manchuria. Within a span of eight years (I9I4-I92 I), the number of counties in Shandong represented among mineworkers grew from eleven in I9I4 to twenty-six in I92I, the number of counties in Hebei grew from four in I9I4 to thirteen in I92I, and the number of counties in Manchuria grew from one in 1914 to six in $1921 .^{66}$ Figure 2 illustrates the growing spatial spread of counties from which mineworkers originated. In I 9 I 4, Shandong mineworkers were from Jimo or counties in central Shandong along the Jinan-Qingdao railway line, while Hebei and Manchuria workers were from Chaoyang, Lingyuan, Linyu (in present-day Qinhuangdao), Fuxin, or Jinxian (present-day Jinzhou). In I92 I, increasing numbers of Chinese mineworkers came from western and south-western Shandong, southern and north-eastern Hebei (especially the areas near Tangshan, where Kaiping Mines were located), and counties in Manchuria near the mine.

The expansion into territories formerly untouched by Fushun recruiters and the migration to Manchuria roused the suspicion of local Chinese government officials. The mine's recruitment in Hebei prompted the governor Zhu Jiabao to contact the Republic of China Ministry of Foreign Affairs (MFA) on 16 December 1916, requesting a formal investigation. ${ }^{67}$ The ministry confirmed the legality of Japanese recruitment, but added a demand for Fushun mine management to provide Chinese officials with information

65. Fujihirada, Manshū ni okeru kōyama rōdō sha, p. I8.

66. Yu, Fushun meitan, p. I49.

67. Xu Youchun, Minguo renwu da cidian (Shijiazhuang, 1991), p. 198. 

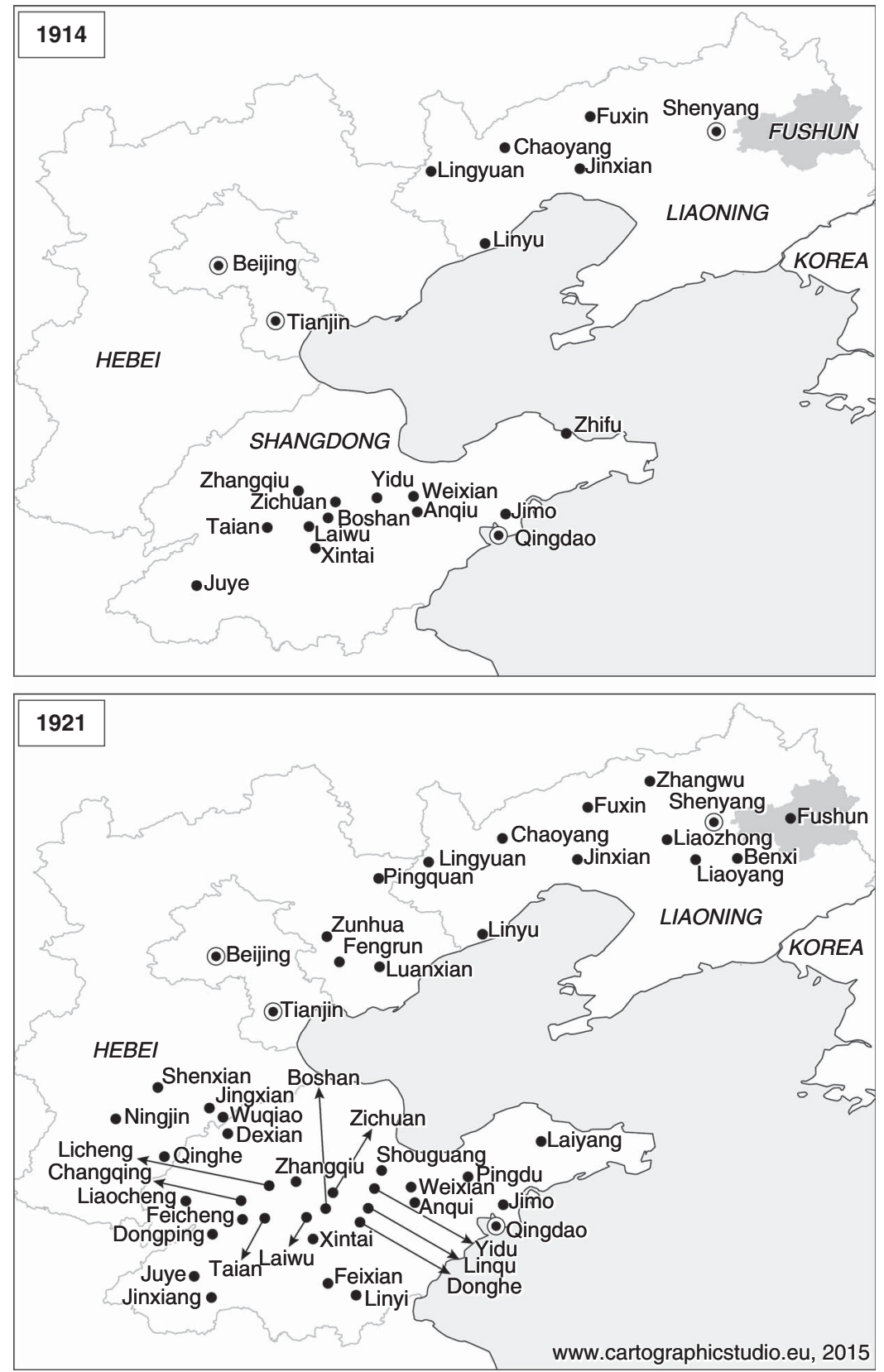

Figure 2. Distribution of mineworkers' places of origin, I9I4 and I92 I. 
on labor recruiters' names, age, place of origin (specifying province, county, and village), name of underground pit where recruiter worked, the labor contractor (batou) in charge of the pit, the month that the recruiter arrived, and the number of workers recruited. ${ }^{68}$ Surprisingly, Japanese mine management complied and supplied Chinese officials with the requested information. According to the mine director's report, 360 recruiters under the supervision of 16 contractors were sent to over 200 villages located in 38 different counties in north China, netting a total of I I,400 men. Judging from archival records, the ministry and local Chinese officials did not do anything with the information supplied, except to file it in the Ministry of Foreign Affairs archives.

Regardless of how precise recordkeeping was or how the collected information was used, this episode reveals another instance of bureaucratization as an attempt at asserting control. It must be remembered that asserting control and gaining control are two different matters. The Chinese state did not, through this small act, stop future recruitment attempts or reverse the trend of increasing Japanese incursion into Chinese sovereignty in Manchuria. Similarly, in its more grandiose plan of bureaucratization Japanese management failed to control labor mobility, let alone slow the rate of labor turnover.

\section{PERSISTENT LABOR MOBILITY}

In I926, Yu Heyin, a Chinese government official, was sent to survey Fushun Coalmine. Yu noted that Chinese mineworkers in Fushun were "frequently on the move". As he reported, "of the I2,000 miners presently employed in the mine, more than 40,000 men had already come and left", which meant that "over I 20 men entered or left employment on a daily basis". ${ }^{69}$ Employment tenure was brief; no miner stayed for longer than six months. The company's statistics of miners hired and dismissed confirm Yu's observations. The earliest figures for labor mobility are from the year 191 2, when the mine needed 7,282 workers. To meet the mine's labor demand, 30,75 I, workers were employed and 29,679 left voluntarily and involuntarily. ${ }^{70}$ These figures meant that the company hired 4.2 workers for a single position. Put differently, it had to hire at least four times to fill a single position in a calendar year. This frequency of hiring translated into an employment stint of only 86.9 days.

This pattern of labor mobility held for the next two decades, even during peak recruitment years. In one of these peak years, 1920, underground mining required II,349 workers. To meet this demand, 58,809 workers

68. Fushun Mine Director to MFA, 2 March I92I, 03-03-015-04-02I, Institute of Modern History Archive, Academia Sinica, Taipei.

69. Yu, Fushun meitan, p. 176.

70. Fujihirada, Manshū ni okeru kōyama rōdō sha, p. 84. For a clarification of these calculations see ch. 3 of Teh, "Mining for Differences". 
were hired - I5, I90 recruits came by way of the company's recruitment network and 43,619 arrived on their own. However, 57,828 left, at various points of their employment, voluntarily and involuntarily. These figures indicate that the company had to hire 5.I 8 workers for each mining position. In other words, the company had to hire at least five times to fill a single mining position in a calendar year. This meant that the average miner's tenure was seventy days. When recruitment slowed due to decline in coal demand, hiring was less frequent and miners stayed a little longer at the job. Two years after coal demand and labor recruitment peaked in I920, the coal market slumped and recruitment shrunk. Only 8,260 miners were needed in 1922. Yet, 26,556 men were hired to fill these positions and 26,343 departed at some point during their employment. SMR had to hire only 3.2 I workers for a single mining position in that calendar year, half the figure for the peak year of I920. Contributing to the slow-down in hiring was the lengthening of the miners' employment tenure. The hired miner stayed for I I 3 days on the job in I 922, which is 43 days longer than $1920 .^{71}$

A factor contributing to the high turnover rate, the government official $\mathrm{Yu}$ pointed out in 1926, was that many miners were from farming backgrounds. Since farming was their primary occupation, they often came in the autumn after the crops' harvest and left in spring in time for the start of the planting season. The migrant workers that the mine recruited in its expansion westward in 1917-1927 were even more likely to return to their farmlands. As Yu's remarks intimated, the migrant workers who came from poorer regions were content to have earned a month's wages. As for the few who were not farmers, Yu explained that they were mostly from Shandong province and were familiar enough with the geography and economic situation in Manchuria to seek out better opportunities elsewhere. As for those with previous mining experience, $\mathrm{Yu}$ found that these allegedly experienced hires had worked in traditional mines that were shallower and the mining work organized differently. Their experience did not prepare them for deep underground mining work that was intense and demanding. Lastly, Yu also noted that those from poorer regions west of Fushun were often content with only 20-30 yuan in their pockets and would not stay longer. ${ }^{72}$ In short, the migrants' farming background, mobility, and their resistance to industrial discipline explained their reluctance to root themselves in Fushun coalmine.

\section{CONCLUSION}

When the Japanese-state-controlled South Manchuria Railway Company took over Fushun Coalmine in 1907, labor supply for the mine was based on a well-established migration pattern between north China and 
Manchuria. Mobilized and mediated by labor contractors originating themselves from the villages in the recruitment areas, peasants and laborers from the Chinese mainland formed a seemingly inexhaustible supply. The high turnover and mobility of these migrants, however, also caused severe problems for Japanese management in building a steady and efficiently organized labor force. Controlling these mobile migratory miners became its main preoccupation. Its main targets were the labor contractors, who had traditionally occupied a quasi-independent intermediary position between management and migrant workers. Fushun managers assumed that control over contractors would grant them control of migration.

Their method was a conscious policy of centralization of labor control after i9i I. All mineworkers became "direct hires", and wages were no longer paid by the contractors but by the mine itself. Fushun opened its own recruitment agencies in Shandong and other recruitment areas as centers for recruiting and evaluating prospective miners, thereby replacing contractors. Contractors were incorporated in the mine's hierarchical structure, and became subordinate to the Japanese authorities in the mine. Last but not least, to administer and control the whole recruitment process, Japanese management introduced fingerprinting as part of an elaborate system of workers' registration. This transformation can be considered a manifestation of a more general trend in the development of labor control in capitalist business from "simple" to "bureaucratic", as described by the sociologist Richard Edwards.

These measures hardly affected the movement of Chinese migrants however. Labor mobility remained a challenge to Japanese management. Because it constantly struggled with the mobility of Chinese labor, Japanese management never succeeded in raising labor productivity. Given that labor mobility persisted throughout the four decades of Japanese management, it is safe to conclude that mine management's bureaucratic measures - from incorporating labor contractors into management to fingerprinting - failed. Chinese workers chose their own way and stuck to their mobility patterns, in spite of all Japanese investments in recruitment procedures and administrative control. 